\title{
The Problems of Teaching Special Lexis (on the Bases of Wood-sawing Sublanguage)
}

\author{
Marina V. Trossel* \\ Siberian Federal University \\ 79 Svobodny, Krasnoyarsk, 660041, Russia
}

Received 12.10.2014, received in revised form 10.11.2014, accepted 12.12.2014

The aim of the article is to point out the problems of teaching Language for Special Purpose on the basis of special lexis of wood-sawing industry. In order to do this the article covers the main features of the sublanguage and its main components - professional popular language, consisting of professionalisms; terminology that is marked by terms, nomenclature-terms, proto-terms; system of terms which is arranged into termonology.

Keywords: sub-language, terminology, system of terms, professional popular language, foreign language at non-linguistic faculties, language of special purpose.

Research area: philology.

In the process of international interaction and due to the standards of present education the graduates of technical higher institutions should be able to continue their further education and be able to work in the field of speciality somewhere abroad. The aim of today education set by state standards of higher and professional education is creating new techniques of teaching the usage of which will help to satisfy the social order for highly skilled and professionally mobile experts able to adapt in promptly changing modern conditions. The graduates must be able to take part in local and international projects, as well as to use the advanced scientific achievements of Russian and foreign scientists available in the Internet.

Taking it into account, teaching foreign languages at non-linguistic faculties is complex and difficult; moreover it faces a number of objective problems such as limited number of teaching hours, low level of foreign language background among students and big workload on their main subjects. So this teaching process needs careful consideration and the rational planning. That is why specialists teaching Language for Special Purpose (LSP further) are to select special lexis thoroughly.

The main principles of teaching LSP were formulated by L.V. Shcherba who differentiated oral and literary language and stated the fact the all teachers' affords should be directed to arranging and limiting linguistic material.

Therefore, it seems obvious that firstly, the students must be given the basic information on LSP and the peculiar features of sublanguage they are going to study.

(C) Siberian Federal University. All rights reserved

* Corresponding author E-mail address: kholodilova_mari@mail.ru 
In modern linguistics the term "sublanguage" has some meanings:

- "set of linguistic elements and their relations in texts on certain topic" (Andreev, 1967);

- special type of social dialect that represents "professional language" (lexical systems) (Bondaletov, 1974);

- functional type of national language, its sub-system that is used in special spheres of social relations (Leichik, 1988);

In this article, sharing the position of V.M Leichik, O.V. Felde, L.I. Varennikova, S.A. Masina and others, a sublanguage is treated as one of various types of national language used by certain group of its users in official and nonofficial communication.

Wood-sawing sublanguage (WSSL further) is a special form of national language that serves certain professional society. As any other sublanguage WSSL is characterized by its variability, dynamism of development and functional-semiotics heterogeneity. The following basic components are outlined: professional popular language, terminology and term system.

Professionalisms - uncodified special units, being a part of professional popular language perform a separate role. Their main peculiar features are: mainly oral character of the usage, figurativeness, possibility of a local variations existence, as well as in most cases existence of synonyms among terminological units.

In the English WSSL a number of professionalisms were determined, among them are the following ones:

- nigger (literary - "a very offensive word for a black person") - "a device for logs turning on front-frame wood-sawing cart". It is known from history that earlier the Black were hired in Western countries for heavy manual labor. Obviously, this very fact caused such metaphorical unit.
- pig man (literary - a person dealing with pigs) - a chokeman: a worker who fixes sawn timber or assortment for further transportation. In this case this is associative metaphor. The work of chokeman is rather dirty and due to this fact the attribute "pig" associating with untidiness and dirt was chosen.

- flayer (literary - a person who hits or whips smb. very hard so that some of their skin comes of) - barker: a worker who barks raw material. Such meaning of this professionalism as taking skin off is equal to technological process of disbarking.

- wood beast (literary - hard material that the trunk and the branches are made of + an animal, especially one that is large or dangerous, or one that is unusual) - a woodsman. Thisprofessionalismappeared due to the fact that a woodsman is taken as mythological character - "beast" - the one who destroys woods.

- hell (literary - a place believed to be the home of devils and where bad people go after death) - kiln for incineration. So the kiln is associated with the hell, where the souls of sinners are burning in fire.

Terminology is very interrelated with professional popular language as it is filled up with professionalisms that become terms. Terminology is understood as "language formation of paradigmatic type, that represents spontaneously formed set of lexical units possessing semantic generality and similarity of formal structure that function all together in one of LSP, denoting general concepts in the field of knowledge or the activity, served by given LSP" (Leichik, 2006).

Terminology is marked by the usage of the following units: terms, nomenclature, 
nomenclature-terms, proto-terms. The main linguistic features of them are the following.

While dealing with special units in WSSL it becomes obvious that a number of them are strictly limited in usage by branch terminology. The examples of such units are:

- wainscot - two-edged cant;

- deal ends - sawn timber of board size in cross-cut, the length of which is less than $2,4 \mathrm{~m}$.

- scroll saw - multi-saw set for cross-cut of timber in which the sawing shafts are fixed.

- strips - sawn timber of thickness less than $51 \mathrm{~mm}$ and width of which is less than 100 $\mathrm{mm}$.

Though there are special units that are widely used in national language and in analogous branches.

Another important unit of spontaneously formed terminology is proto-term. It is a unit that denotes some object, phenomena, process or its feature or quality. In the judgment of S.V. Grinev, proto-terms basically appear and function in pre-scientific period (the earliest ones, probably $30,000-40,000$ years ago). That is why this units have no links with scientific notions and they denote special notions but for concepts that appear simultaneously with the science. This type of special units does not disappear since time. It remains in handicraft and everyday lexis. Many special units of this type penetrated into everyday language. The reason of this is a rise of new scientific disciplines. A part of prototerms that are steadily used in special language is transformed into scientific concepts. The units that are not codified exist in everyday language or become a part of so called "folk terminology" that functions simultaneously with scientific terminology. Thereby a number of basic terms of old terminology were once proto-terms and preserved some characteristic features since then such as the use of casual, surface signs for motivation or absence of any motivation at all.

Among proto-terms functioning in WSSL one can mark the following units: board, log, pole, timber, planks, to trim, axe. These units are used in all functional-semiotic zones of sublanguage including professional popular language.

Pre-term is another type of special unit. Preterms are used to denote scientific concepts of newly formed sciences. Terminologists believe that such special units are used as terms to denote new concepts as they do not have proper terms yet. (O.V. Borhwald, 2000). As a result these units are characterized by multi-word form, form fluctuation, instability of value. They are permanent in use and subsequently they whether disappear or become terms. In some cases these units are characterized by emotional nuance. As a rule proto-terms are:

- descriptive phrases - nominating multiword combination used in order to name a concept. This way of nomination gives possibility to describe its essence, but, unfortunately, the demand of brevity is not followed. E.g.: two-side band grinder, green chain tally foot, internal fan kiln, joiner's cross-cut saw bench, etc.

- combination with a Participle, e.g.: planning and thickening machine, bark stripped from trees, half-radial cut board, hollowed-out log, knee-and-column type milling machine, etc.

Nomenclature-terms are considered to be another type of special units that are also widely spread in WSSL. Quite often the formation of a system of terms starts from these units. A.V. Superanskaya points to this fact: "During the process of scientific branches' development some nomenclature units become terms, so they transfer from lexical nominating units into the units of logical message, i.e. into the terms of science" (Superanskaya, 1989). 
The majority of nomenclature units are characterized by conditionality of meaning, independence from context, the ability to form linear series. The nomenclature units can be rather long, compound that is not typical for general lexis. Because of this fact many units of this kind in WSSL are abbreviations, e.g.: ad (air-dried), $C L$ (centerline), $W W C B$ (wood wool cement board), $\operatorname{dim}$ (dimension), FAS (firsts and seconds), etc.

Nomenclature units can consist of letters, numbers and special symbols, e.g.: $t \& g$ (tongue and groove), $D \& S M$ (dressed and center-matched), SIE (surfaced one edge), SISIE (surfaced one side and one edge), S2\&CM (surfaced two sides and center-matched), etc.

Besides there exists a number of nomenclature units, like Logosol, Canima, Buldog, Professional, Paul, Joint, etc. These units denote different wood-equipments and are motivated by names of their producers. So Canima is a firm producing edging line; Logosol is a firm producing sawing machines; Buldog is a firm producing sanding machines. In professional sphere one can hear such nomenclature units as Harvester, Farmer (these are sawing machines), STIHL (saw), WoodMizer, Kanefusa (band saws) and so on.

In general special units of this type in WSSL are motivated by "ideological" feature, that according to Z.I. Komarova "reflects new idea concept of the epoch". (Komarova, 1991)

Therefore, the study of special lexis of WSSL makes it possible to find effective means of teaching LSP. Existence of terms-combinations gives opportunity to make up Students' Vocabularies that would be useful while working with special texts (reading, translating, picking up necessary information and so on) as well as enlarging professional vocabulary that is essential in professional communication.

As it was stated above one of the problems in teaching LSP is not enough time given to this discipline, it is obvious that the syllabus should be well planned. One of the ways out is to spend the first year on forming certain terminological minimum - terminology, system of terms and professional popular language. Unfortunately, the last one in most cases stays beyond studying process that is extremely wrong.

The students of second course are supposed to work with text on their specialty. These texts are to train students' ability to read and understand information from the field they are specializing in. Moreover, these texts give a background for further discussions on special topics. One more skill that is professionally important and should be trained at classes is work with special references - dictionaries of terms, abbreviations, branch standards and so on.

\section{References}

1. Averbooh K.Y. General Theory of Term: complex-variological approach : doctors dissertation. Ivanovo, 2005. (in Russian).

2. Alekseev M.P. Russian Language in World Cultural Use // Linguistic Problems. 1984. № 2. Pp. 3-13. (in Russian).

3. Alekseeva L.M. The Problems of Term and Termformation Teaching Aid for special course. Perm, 1998. (in Russian).

4. Alimov V.V. Theory of Translation. Translation in the Field of Proffesional Communication. URSS, 2000. (in Russian).

5. Andreev N.D. Statico-combinational Methods in Theoretical and Applied Linguistics. Leningrad, 1967. (in Russian). 
6. Bondaletov V.D. Reference Languages of Russian Craftsmen and Traders: Reference Languages as Special Type of Social Dialects. (Ryazan, 1974) (in Russian).

7. Borhwald O.V. Russian Language Historical Study of Terminology. (Krasnoyarsk, 2000) (in Russian).

8. Corkhill T. A Glossary of Wood. London, 1948.

9. Denisov P.N. The Lexis of Russian Language and Principles of its Description. Moscow, 1993. (in Russian).

10. Elsevier, Elseviers Wood Dictionary. Amsterdam, 1964, Vol. 2.

11. English-Russian Forestry-engineering Dictionary. Moscow.: Russkiy Yazyk Press, 1983.

12. Grinev S.V. Introduction to Terms codification. Moscow.: Moscow Pedagogical University, 1995. (in Russian).

13. Kholodilova M.V. English-Russian, Russian-English Dictionary of Wood-sawing lexis. Krasnoyarsk, Krasnoyarsk State Pedagogical University Press, 2009.

14. Komarova Z.I. Semantic Structure of Special Unit and its lexicographic description. Sverdlovsk: Uralskiy University Press, 1991. (in Russian).

15. Leichik V.M. Terminology Study: subject, methods, structure. Moscow, 2006. (in Russian).

16. Leichik V.M. The Main States of Comparative Terminology Study // Branch Terminology and its structural-typological Description. Voronezh: Voronezh University Press, 1988. pp. 4-10. (in Russian).

17. Lyah N.I., Sychov A.N. Terminological Dictionary. Krasnoyarsk, 2004. (in Russian).

18. McCulloch, Fraser W. Wood Words. A comprehensive dictionary of logger terms. Oregon, 1958.

19. Mozhaev D.V., Novikov B.N., Rybakov D.N. English-Russian, Russian-English Forestryengineering Dictionary. Moscow, 2004.

20. Superanskay A.V., Podolskay N.V., Vasilieva N.V. General Terminology: Theory Problems. Moscow: Nauka Press, 1989. (in Russian).

21. Varennikova L.I., Massina S.A. Types of Special Lexis and their extra-linguistic conditionality // Language and Society. Issue 9, Saratov, 1993. (in Russian). 


\section{Проблемы обучения языку для специальных целей}

\section{на примере специальной лексики}

\section{подъязыка лесопильной промышленности}

М.В. Троссель

Сибирский федеральный университет Россия, 660041, Красноярск, пр. Свободный, 79

В статье затрагивается проблема обучения языку для специильных целей на примере специальной лексики подъязыка лесопильной промышленности. Для этого рассматриваются основные особенности данного подъязыка, его главные составляющие - профессиональное просторечие, представленное профессионализмами; терминология, маркирующими единицами которой являются термины, номины, терминонимы и прототермины; терминосистема, которая представляет собой терминологию в упорядоченном виде.

Ключевые слова: подъязык, терминология, терминосистема, профессиональное просторечие, иностранный язык на неязыковых факультетах, язык для специальных ичелей.

Научная специальность: 10.00.00-филологические науки. 